\title{
Healthcare Policy in Romania. Frameworks and Challenges
}

\author{
Călina Ana Buțiu1 ${ }^{*}$ \\ 11 Decembrie 1918 University of Alba Iulia, Department of Social Sciences, 15-17 Unirii Street, 510009 - Alba \\ Iulia, Romania
}

KEYWORDS

Healthcare system

Public health

Social exclusion

Social inclusion strategy

\section{A BSTRACT}

The objective of the paper is to review some of the healthcare policy issues of Romania and identify those challenges which may be addressed through social intervention. Based on statistical data, documents, reports and applicable laws one will review the health condition of Romanian population and the state of the national health system, and will examine the broad strategies and policies currently under the scrutiny of appropriate ministries. The findings of the study suggest looking at health policies also through the lens of social inclusion.

\section{Theoretical background}

Modern society faces many critical problems and, although the progress in science in technology had provided a rich source of solutions, not all problems find their answer in positive sciences; some issues can only be addressed through political means, as Dror (1983) stated. Political science seeks answers to questions on the nature, the causes and the effects of various policies by resting on a continuously developing and diversifying body of theoretical knowledge and by engaging more and more sophisticated methods and instruments. Richard Rose (2005) argues that the activity of governments should consist of interrelated activities to some extent. Otherwise, decisions taken in isolation cannot be considered as

\footnotetext{
* Contact address: bcalina@yahoo.co.uk (C.A. Buțiu)
} 
elements of public policy. As a matter of fact seldom do we see any public problem solved by singular decisions.

Health in its consecrated, medical understanding refers to the vitality to perform organic functions or, in a negative perspective, the absence of illness. This conventional, negative connotation, according to Baggott (2011) has gained momentum due to advances in medicine and to the commercial development of medical services. From public perspective however one can take a more positive view by looking at the social, environmental and psychological well-being of society. It is true that the determining factors in the health of a population are primarily biological and sometimes genetically-rooted, but individual behaviour and societal conditions also contribute to the ultimate health and well-being of individuals.

Bryant (2009) defines a health policy as being a subset of a public policy. In another simple definition Porche $(2012,6)$ defines public health policies as being those policies outlined by the legislative, executive or judicial power that set the course of actions which will affect the health of the population. One should remark the onus put on all three powers of the state in having responsibility for the health of the population. If one accepts that health is a public good then its non-exclusivity and non-rivalry qualities must be attached too. This in turns suggest the impossibility of provisioning it through free market mechanisms. Regulatory authorities have a wide range of instruments to replace market mechanisms. Among these one can mention prohibitions, licensing, price, rate, and quantity restrictions, product standards, technical production standards, performance standards, subsidies information provision, and assigning property rights and liability (Eisner, Worsham, and Ringquist 2000, 13).

Public healthcare is one of the major challenges for both individuals and governments alike in today's context of rapid developments in the medical services industry. As spectacular as medical progress may be, the benefits of it are not always harmonized with individual real needs of a higher life quality. In terms of quality of life, the health component does not include just an individual's health, but also the level of access to health 
services and the way these services can be utilised. Also one may include behaviour, attitudes and values in regard to health. (Pop 2010, 280).

Public healthcare is a social construct because it could not have existed had we not built it' says Bhattacharya (2013). A commonly agreed definition of public healthcare still doesn't exist. Seltzer states that the public health expert considers health from the perspective of entire communities, neighbourhoods, cities and states. Public health even addresses disease prevention and health promotion on a national and global scale' (Seltzer 2011, 3). Other definitions are claimed as being positive for looking at the health and not at the illness and for focusing on public policy. 'Public health is a role of local state, and national government in assuring conditions in which people can be healthy' (Carter and Slack 2010, 2). For this study we will assume the latter as a working definition. The history of modern public healthcare is littered with major changes. The dramatic impact of widespread communicable diseases like flu or poliomyelitis, the development of vaccines to address illnesses such as measles in children, the wide use of antibiotics for various infections, the appearance of public threats like AIDS, all brought a significant contribution to the development of public policies (Matthews 2009, 28). Holdinger and Schutchfield consider that after the attacks of September 11, 2001 on the World Trade Center and on the Pentagon 'the new century epidemic is terrorism and bioterrorism, and the response is public health preparedness' (Holsinger and Scuthfield 2013, 18).

The new public healthcare includes health education, social marketing, epidemiology biostatistics, diagnosis screening, immunisation, public participation in policy making, cross-sector collaboration, ecology, health advocacy, and health economics. All of the above are in addition to or replace traditional approaches in disease coping like quarantine, isolation or sanitary inspections. (Petersen and Lupton 2000, 5).

A sensitive problem in the domain of public health is that of professional ethics. Hester $(2006,1)$ argues that in that respect public health is unique in that it is constantly concerned with communal rather than 
universal objectives which unavoidably require the sacrifice of individual interests.

In order to achieve a comprehensive public health policy one needs to consider the needs of and the impact on all the stakeholders. This is why most public policies can only be drafted by a series of decisions taken in concert by several decision makers from different ministries or departments. One should also consider that there are limits to policy making due to a lack of resources or to resistance from some of the stakeholders. Public policies are designed with certain goals in mind, truism that is also stated by William Jenkins (1978) when he says that public policies are decisions taken by governments, decisions that establish a precise goal and state the means through which it can be achieved.

The cast of actors which participate in the policy making process is diverse, as mentioned, and includes not only the decision-makers, but also the decision-implementers, those that have a say in the content, the execution or the implementation of the policies. It includes in other words not just entities of state (ministries, commissions, agencies, etc.) but also those of civil society like unions, NGOs, advocacy groups and other interests directly or marginally involved in the public process (Păceşilă 2008).

The work of Buse, Mays and Walt (2012) iterates the contextual factors which influence the policy for public health. Out of those, the political system is mentioned as being a relatively stable structural factor. In democratic countries the political system generally supports the principles of social justice and recognizes them as facilitators of public welfare. Social justice according to Powers and Faden $(2008,10)$ aims to improve human well-being and to do so in particular by focusing on the needs of those who are at the most disadvantage. On that line of thought, improving the health of the population as an element of the quality of life requires among other things the reduction of inequalities (Pop 2010).

European Union's poverty and social exclusion combating policy has been clearly articulated in the Lisbon Treaty social agenda which introduced the concept of social inclusion. The Anti-Poverty and Social Inclusion Plans 
drafted at Nice 2000 European Council Meeting have reaffirmed this social agenda subject (COM 2010). Romania's social assistance law no. 292/2011 defines social inclusion as a set of measures and multi-dimensional actions in a multitude of domains (of social protection, housing, education, health and communication) through which the state ensures vulnerable persons' access to some of the fundamental rights among which also is the right to medical assistance.

In World Health Organization's 2014 'Qualitative indicators for monitoring Health 2020 policy targets' report, all countries replied on the existence of a national or sub-national policy or strategy addressing health inequities or social determinants of health. The most frequent policy reported to reduce health inequities or tackle social determinants of health in 2010 was the focus on disadvantaged groups (87\% of respondents). Important increases of more than 20\% over the period from 2010 to 2013 were reported on policies focusing on poverty (from 67\% in 2010 to $90 \%$ in 2013) and human rights (from $63 \%$ in 2010 to $87 \%$ in 2013). Other frequent elements that increased more than 10 percentage points were related to environment and universal health coverage. (WHO 2014: 5).

\section{The status of public healthcare in Romania through a comparative analysis}

A series of reports and studies mention a precarious condition of population's health in Romania when compared with other European countries.

The 2014-2020 National Health Strategy documents mention that the socio-economic factors play an important role in the level of health, poverty being a noticeable indicator. Romania is one of the poorest countries in the European Union. Approximately $42 \%$ of Romanian population is at risk of poverty and social exclusion, Bulgaria being the only country faring worse (Buțiu 2014, 161). Other health-related relevant indicators pertain to individual behaviour, showing excess tobacco and alcohol consumption, physical inactivity, and bad diet leading to heart disease and obesity. 
Alcohol intake, smoking, salt and saturated fat consumption levels of Romanian adults are highest in Europe (Ministry of Health 2014, 15-16).

A 2011 World Bank report shows that the Romanian health system falls short of health outcomes in richer nations, but it performs well relative to countries with similar income levels (Word Bank 2011, 9). Life expectancy at birth - one of the leading indicators at which Malta for example is faring best in the EU - is lower for countries like Hungary, Bulgaria and Romania. In Table 1 one can see that Romania made some progress between 2004 and 2013, but it still ranks at the bottom overall, only fellow ex-communist Bulgaria being slightly worse.

Table 1: Life expectancy at birth in selected EU countries

\begin{tabular}{|c|c|c|c|c|}
\hline \multirow{2}{*}{$\begin{array}{c}\text { COUNTRY } \backslash \text { YEAR } \backslash \\
\text { GENDER }\end{array}$} & \multicolumn{2}{|c|}{2004} & \multicolumn{2}{|c|}{2013} \\
\hline & Female & Male & Female & Male \\
\hline $\mathrm{EU}(28$ countries $)$ & 81.5 & 75.2 & 83.3 & 77.8 \\
\hline Malta & 81.2 & 77.4 & 84.0 & 79.6 \\
\hline Bulgaria & 76.2 & 69.0 & 78.6 & 71.3 \\
\hline Hungary & 77.2 & 68.7 & 79.1 & 72.3 \\
\hline România & 75.1 & 67.8 & 78.7 & 71.6 \\
\hline
\end{tabular}

Data source: Eurostat

(http://ec.europa. eu/eurostat/tgm/table. do?tab=table\&init=1 \&plugin=1\&language=en\&pcode=tsdph100)

The table also depicts a visible difference between sexes, European women expecting to live an average of 5 years more than men. This difference is even greater for Hungary, Romania and Bulgaria, at 7 years, and has not changed between 2004 and 2013.

According to statistical data for both sexes most of the potential years of life lost as a result of premature deaths in Romania are the result primarily of cardio-vascular disease and hepatic cirrhosis, with breast and pulmonary cancer raking fifth for women and fourth respectively for men (Ministry of Health 2014, 12).

The Morbidity Profile as outlined in the Romanian Health Alliance report for the last four decades underwent significant changes; the main conditions of the 70's like digestive and respiratory diseases and infections have dropped in frequency or have been brought under a reasonable 
control, with other pathologies becoming more frequent. The fastest increases over the decade can be seen in the rates of endocrine and metabolic conditions at $43 \%$, of circulatory conditions and tumours, both at $29 \%$, and of mental disorders at 24\% (The Romanian Alliance for Health n.d., 5).

Healthy Life Years at Birth is also a relevant indicator for public health. Table 2 depicts some significant differences between genders in different countries at different points in time. The first thing to notice is that although women tend to live longer than men overall, they have lower chances at the number of healthy years. This aspect negatively affects women's quality of life and the tendency is away from that of men's. Concretely while the gender difference in Romania was $5.6 \%$ in 2007, it went up to $8.2 \%$ in 2013. With the exception of Malta, is also noticeable a tendency of a decrease in the proportion of healthy years to the total life expectancy years for both genders during the same period; the most dramatic decrease is in Bulgaria, who occupies the bottom spot at other indicators too (Buțiu 2014).

Table 2: Healty life expectancy at birth in selected EU countries

\begin{tabular}{|c|c|c|c|c|c|c|c|c|}
\hline \multirow{3}{*}{$\begin{array}{c}\text { COUNTRY \YEAR } \\
\text { GENDER }\end{array}$} & \multicolumn{4}{|c|}{2007} & \multicolumn{4}{|c|}{2013} \\
\hline & \multicolumn{2}{|c|}{ Female } & \multicolumn{2}{|c|}{ Male } & \multicolumn{2}{|c|}{ Female } & \multicolumn{2}{|c|}{ Male } \\
\hline & Years & $\%$ & Years & $\%$ & Years & $\%$ & Years & $\%$ \\
\hline $\mathrm{EU}(27$ countries $)$ & 62,0 & $76,1 \%$ & 61,7 & $81,1 \%$ & - & - & - & - \\
\hline Malta & 71,7 & $86.5 \%$ & 68,2 & $89,3 \%$ & 72,7 & $86,6 \%$ & 71,6 & $90.0 \%$ \\
\hline Bulgaria & 73,9 & $96,4 \%$ & 67,1 & $96,5 \%$ & 66,6 & $84,7 \%$ & 62,4 & $87,5 \%$ \\
\hline Hungary. & 57,8 & $74.3 \%$ & 55,1 & $79,4 \%$ & 60,1 & $76,0 \%$ & 59,1 & $81,8 \%$ \\
\hline România & 62,5 & $81.4 \%$ & 60,5 & $87,0 \%$ & 57,9 & $73.6 \%$ & 58,6 & $81,8 \%$ \\
\hline
\end{tabular}

Note: (\%) represents the proportion of healthy life expectancy at birth in years to total life expectancy at birth, also in years

Data source: Eurostat (http://appsso.eurostat.ec europa eu/nui/submitViewTableAction.do)

The self-perceived health is an indicator of the psychological wellbeing of respondents. If one looks at this perception of adults over 65 years of age one can see significant differences between Romania and other European countries. In 2014 only 19.3\% of Romanians felt themselves as having a good and very good health in comparison with the EU average of $37.6 \%$. Gender-wise 10\% more Romanian men than women feel in good 
health. ${ }^{1}$ For the same age cohort the lower opinions of self-perceived health according to Eurostat ${ }^{2}$ seem strongly associated with lower incomes, fact which raises the question as to what degree poverty creates a negative selfperception of health. The differences between the self-perception of being in a good and very good health of the first and the fifth quintile of equivalised income is greater than $10 \%$ for Romania, but even greater than EU average (Table 3). Most likely, the expectations of better health and of easy access to health services are greater in countries with higher quality of life. Also noticeable is the difference between men and women whereby women tend to be less satisfied with their health, regardless of their economic status, but noticeably less so in poorer than EU average countries like Romania.

Table 3: Self-perceived health as being good and very good for adults over 65 years of age

\begin{tabular}{|l|c|c|c|c|}
\hline \multirow{2}{*}{ COUNTRY $\backslash$ TILE $\backslash$ GENDER } & \multicolumn{2}{|c|}{$\begin{array}{c}\text { First quintile of } \\
\text { equivalised income }\end{array}$} & \multicolumn{2}{c|}{$\begin{array}{c}\text { Fifth quintile of } \\
\text { equivalised income }\end{array}$} \\
\cline { 2 - 5 } & Male & Female & Male & Female \\
\hline EU(27 countries $)$ & $23,6 \%$ & $13,0 \%$ & $31,5 \%$ & $24,6 \%$ \\
\hline România & $34.0 \%$ & $29,1 \%$ & $53,0 \%$ & $47,3 \%$ \\
\hline
\end{tabular}

Data source: Eurostat (http //appsso. eurostat. ec europa eu/nui/submitView TableAction. do)

The data in Table 3 is also supported by more objective indicators like the healthy life expectancy from Table 2 and the total life expectancy from Table 1. The lower the healthy life expectancy and the total life expectancy indicators are, the less positive self-perceived level of health appears to be.

\section{Healthcare system in Romania}

National healthcare systems are complex social organisations that continuously develop and supply health services. The power centres inside these systems have different functions, interests and expectations. Generally

\footnotetext{
${ }_{1}^{1}$ According to Eurostat (http://appsso.eurostat.ec.europa.eu/nui/show.do).

2 Eurostat (http://appsso.eurostat.ec.europa.eu/nui/submitViewTableAction.do).
} 
speaking national healthcare systems are unstable for they are subject of external factors and of influences arising from the power centres. The resulting changes can sometimes be beneficial, but may also bring damages. Decision makers in public healthcare systems are under continuous pressure to adjust objectives and to cope with long-term evolutions like medical progress, cost increases, political demands and the overall increase in healthcare needs of the society. They must continuously balance the higher demands with minimal costs and make hard choices when resources are limited.

To some extent, the healthcare system of Romania is tributary to its pre-1989 ancestor. Looking at healthcare systems of several ex-communist countries M. Roemer (1993) claims they are the result of ideological factors like the socialist goal of free, universal and complete coverage, of managerial factors like the soviet-style monopolistic management philosophy, of financial factors like the lack of free-market financing, of structural factors that result in a poor quality of primary care and of organisational factors which lead to rigidity, lack of standards and an overall unresponsiveness to the needs of the patients.

The current healthcare system of Romania is subject to the public healthcare system reform Law no. 95/2006 drafted by parliament, law that was subsequently amended and that resulted even since 2012 in calls for modification or complete replacement due to several dysfunctionalities stated in a new healthcare system organisation call for submissions. A new bill in that respect has not been passed yet, the system continuing to function within the 2006 framework.

The main challenges of Romanian healthcare system are those of costs and of quality of services. Cost issues have to do with insufficient funding and inefficient spending. Legislative and professional managerial roadblocks coupled with defective financing lead to frequent drug and consumable shortages. In addition there is also the issue of informal payments like tips and bribes to doctors and nurses alike, payments that distort the equitable 
access to services and act as a de facto rationalisation method of medical services (Ritli 2012).

According to a June 2014 Eurobarometer publication, 73\% of Romanian patients - as opposed to $27 \%$ of EU 28 average - consider the quality of health services as being poor (European Commission 2014, 12). Increased costs result in a decrease in access to services. According to the self-reported unmet needs for medical examination rates from Table 4, Romania is faring considerably worse than EU-28 average.

Table 4: Self-reported unmet needs for medical examination for being too expensive

\begin{tabular}{|l|c|c|c|c|}
\hline \multicolumn{1}{|c|}{ COUNTRY $\backslash$ YEAR } & 2010 & 2011 & 2012 & 2013 \\
\hline European Union $(28$ countries) & $1.9 \%$ & $2.3 \%$ & $2.2 \%$ & $2.4 \%$ \\
\hline Romania & $9.5 \%$ & $10.4 \%$ & $9.2 \%$ & $9.0 \%$ \\
\hline
\end{tabular}

Data source: Eurostat (http://appsso.eurostat.ec.europa eu/nui/show.do)

Statistics show further that medical expenses in Romania have systematically been lower not just than the EU average but even than those of ex-communist countries. Notwithstanding of course that most European countries have higher incomes, in 2013 Romania barely spent EUR 371.88 per capita for healthcare expenses (World Bank 2011, 7) in comparison with the top spender Norway who spent EUR 6,911.55. ${ }^{3}$ According to Evans et al. (2001), the effectiveness of a healthcare system is directly proportional to its per capita funding. Despite the increase in healthcare budget both in real terms from EUR 90 per capita to over 200 and in \% of GDP from 3\% to 4\% during the past few years, Romania continues to lag behind in the amount of resources it allocates to healthcare. ${ }^{4}$

The privatisation of medical services in Romania occurred with different speeds for different specialties. The fastest and most spectacular change happened to pharmacies and to dental cabinets (Table 5). The pharmaceutical assistance to the population is legislated via Pharmacy Law 266/2008 of the Romanian Parliament which implements the EU human

\footnotetext{
3 See Eurostat (http://appsso.eurostat.ec.europa.eu/nui/submitViewTableAction.do).

${ }^{4}$ See Eurostat (http://appsso.eurostat.ec.europa.eu/nui/show.do).
} 
drug use communitarian Directive 2001/83/CE of the European Parliament and via the Health Reform Law 95/2006 of the Romanian Parliament.

Table 5 : The evolution of private medical services in Romania

\begin{tabular}{|l|r|r|r|r|r|r|r|}
\hline \multicolumn{1}{|c|}{ MED.UNTSS YEAR } & 2008 & 2009 & 2010 & 2011 & 2012 & 2013 & 2014 \\
\hline No. of Specialty Clinics & N/A & N/A & N/A & 23 & 27 & 39 & 48 \\
\hline No. of Family Doctors Cabinets & 2713 & 3213 & 4402 & 4992 & 5158 & 5649 & 5688 \\
\hline No. of Dental Cabinets & 7923 & 8830 & 9697 & 10528 & 10953 & 11931 & 12502 \\
\hline No. of Phamacies & 5645 & 6005 & 6190 & 6565 & 6823 & 7154 & 7421 \\
\hline No. of Medical Labs & 812 & 954 & 1193 & 1272 & 1305 & 1362 & 1458 \\
\hline
\end{tabular}

In Romania the primary assistance system was the first to undergo major changes after 1989 and it still is to date the most significantly organisationally altered component of the public system.

Notwithstanding the recognition of primary assistance as a first line priority by successive administrations, the allocated resources have repeatedly been less than the EU average and never surpassed the $10 \%$ of total expense supplier budget threshold of the National Health Insurance House, typically hovering around 6\% of total expense (Ritli 2012).

Specialty clinics have benefited even less. Ministry of Health Order 39/2008 article 4 paragraph 1 stipulates the obligation of each hospital unit having beds to self-organise the integrated specialty clinics. The resulting small number of private ambulatory specialty clinics seems to suggest there aren't many private hospitals in Romania (Table 5).

As for the public healthcare units, Table 6 shows a general decline in numbers, public dental cabinets for instance declining by half in seven years and public pharmacies not only declining in numbers, but having been ten times fewer than private ones in 2008 and ending up 18 times fewer in 2014. A quasi-equilibrium between the number of public units and that of private units appears to exist for specialty ambulatory clinics and family doctors' cabinets. 
Government Decision 400/2014 (Govt. of Rom. 2014a) regulates the medical assistance contract framework which includes the minimal and basic medical service packages. The basic package according to this law refers to the basic set of services offered free to all residents insured by the national insurance scheme and the minimal package includes services available to anyone left outside this scheme (uninsured). Minimal package thus includes emergency services, pregnancies, immunisations and vaccinations.

Table 6: The evolution of public medical services in Romania

\begin{tabular}{|c|c|c|c|c|c|c|c|c|}
\hline MED.UNTTS \YEAR & 2007 & 2008 & 2009 & 2010 & 2011 & 2012 & 2013 & 2014 \\
\hline No. of Specialty Clinics & 92 & 64 & 62 & 59 & 57 & 58 & 53 & 49 \\
\hline $\begin{array}{l}\text { No. of Family Doctors } \\
\text { Cabinets }\end{array}$ & 8524 & 8566 & 8177 & 6768 & 6219 & 5993 & 5509 & 5475 \\
\hline No. of Dental Cabinets & 3123 & 3102 & 2853 & 2339 & 2085 & 1951 & 1527 & 1550 \\
\hline No. of Phamacies & 481 & 482 & 501 & 492 & 404 & 403 & 406 & 404 \\
\hline No. of Medical Labs & 1547 & 1743 & 1874 & 1785 & 1736 & 1943 & 1928 & 1960 \\
\hline
\end{tabular}

As a result of imbalances between the number of public and the number of private services available, some demands of patients cannot be satisfied. According to Ministry of Health and of National Health Insurance House Order 44/53/2010 the public system works on a first-in, first-served scheduling basis, which results in long waiting queues spanning for months for most services and even years for those services in short supply. Radiology and Imaging departments are notorious examples where queues are ubiquitous and where many insured patients end up paying private equivalent services, rather than assuming long waits that could be detrimental to their health. ${ }^{5}$ The same situation is encountered at medical analysis labs where patients may either postpone other procedures because of delayed blood test results or pay out of the pocket at a private lab. Because of that the number of private labs has mushroomed, some of the

\footnotetext{
5 An MRI scan for instance, which is widely utilized for diagnosis these days, may cost anywhere from 100 to 700 euros, depending on the number of areas of investigation; this in a context where the average monthly salary in Romania is EUR 600.
} 
financial burden from the public system is being 'farmed-out' at the expense of the otherwise insured beneficiaries. And then, there are possible lifesaving procedures like cancer immunotherapy which in public facilities are available only as a trial on a random 50-50 chance of selection - in other words prohibitive for $50 \%$ of the patients in public care - and virtually $100 \%$ prohibitively expensive in private care.

\section{Current health management strategies and solutions in the European Union and in Romania}

In his September 2002 speech, David Byrne, European Commissioner for Health and Consumer Protection, made a significant assertion: there can be no Europe, without a Europe of Health. In an enlarged European Union, moving away from a multitude of small projects and towards broad, horizontal and sustainable actions, he suggested the following headlines being appropriate for a European health policy: (1) to prepare a solid basis for policy development by creating a large-scale system of health information, (2) to invest in finding ways to respond effectively to health threats, (3) to influence the determinants of health, tackling the major burdens of disease.

Paula Franklin (2013) offers a bird's eye view of two current health strategies for Europe, the WHO Regional Office for Europe's strategy and the European Commission Directorate for Health and Consumers (DG SANCO)'s 'Together for Health' strategy, both of which bring into question the issue of governance and the role of public financing. Thus public healthcare is placed in a larger context in which an unstable economic situation could affect it profoundly. In response, the decision makers in the main institutions (WHO and EC) acknowledged the importance of sound investment in healthcare. Both European strategies acknowledge healthcare as a value in itself and as a priceless component of economic systems. According to Paula Franklin, the two strategies cover different positions in Europe and use different means of operation. The public health and welfare 
community acknowledges European Commission strategy as being vital to defend the important role of healthcare on European Union's agenda and the political framework of WHO's strategy is accepted as a valuable instrument in the service of member states.

World Health Organisation's strategy states two major objectives: (1) the improvement of health for all and the reduction in health inequalities and (2) the improvement in leadership and in participatory governance for health. The first objective encourages national governments to take action in order to reduce inequalities, which translate into intervention for the benefit of the worst affected, to address the social gradient in health directly, and to intervene proportionally to the level of health and to social needs. This first objective also requires a realignment of the mechanisms, relationships and institutional arrangements among different sectors. Towards meeting the second objective, Health 2020 strategy promotes collaborative leadership through innovative approaches in order to address behavioural, environmental and healthcare issues. The Health 2020 strategy includes many essential concepts that have not previously been routinely measured, so a broader scope that covers them is needed to optimize monitoring. Examples include transparency, community resilience, supportive environments, enabling environments, sense of belonging, sense of control, whole-of-society approach, participatory governance, responsible governance, accountability, life-course approach, empowerment, peoplecentred health systems, fit-for-purpose health systems, adaptive policies (WHO 2013).

The ultimate goal of all development is to improve the prerequisites for long-term survival and the well-being of the population which implies social inclusion measures and a more equitable distribution of the social determinants of health. To create positive sustainable changes a participatory stake holder's engagement approach should be used. Health 2020 strategy recognizes that each contribution's value is not only practical but also collaborative and empowering in finding solutions together. For 
that reason WHO (2015) asks governments to implicate a range of stakeholders at all levels.

Government of Romania's Decision no. 1028/2014 concerning the approval of the National Health Strategy 2014-2020 and the action plan for 2014-2020 is attempting to implement the Europe 2020 WHO strategy at national level, as part of a wider group of seven symbolic EU initiatives. The document has also been drafted having in mind the European funds accession process and the pre-conditions agreed in the Partnership Agreement between Romania and the European Commission, as well as the sanitary sector recommendations made by the European Commission.

Considered by some as an example of libertarian paternalism, ${ }^{6}$ the strategy is in Lucian Isar's (2014) opinion a broad and complex medical service optimization exercise under the strain of budgetary restrictions.

The approach to healthcare management appears radically different from the previous one by proposing a 'reversed pyramid' model in which the first line of services would be provided by ambulatory community clinics rather by public hospitals as in the old approach. Instead of stretching the resource limitations of public hospitals, it would be the community service providers like family doctors and ambulatory community clinics that would offer first line assistance and act as a filter, allowing passing through only the most severe cases which require hospital resources.

\section{Discussion}

When looking at the key elements of public policies and at the means through which political actors approach problems one can argue that the chief public policy decision makers (The Parliament and Government of Romania) are taking reactive rather than proactive decisions, the main instruments being legislative ones. Strategies are formulated that are either inapplicable or end up simply neglected.

\footnotetext{
${ }^{6}$ The theory of libertarian paternalism is relatively recent and it includes the claim that there are ways through which the state can influence the behaviour of the individuals while at the same time allowing them free choices.
} 
From prevention perspective some measures are enacted like the banning of smoking in public places or of advertising unhealthy lifestyles, but these actions are isolated initiatives, not part of a coherent strategy. At times these initiatives are symbolic or are being taken because of pressures from the European levels.

Research and innovation in health are issues that don't seem to capture the attention of political decision makers. Out of all EU countries Romania appears to systematically allocate the smallest percentage of GDP for research. ${ }^{7}$

When actions that lack vision are taken, negative effects manifest on the public. The example of pharmaceutical products is by now notorious, for many fraud and corruption scandals made headlines in national papers. The mushrooming of highly priced, highly profitable private pharmacies in a country that is the second-poorest in the European Union is an indicator of large public monies being siphoned out of state's resources.

Access to quality medical assistance is restricted for those with low disposable incomes, the result being the degradation of the population's health followed by the negative economic effects of a drop in work capacity and consequently in income levels. This vicious circle traps poor families in a state of social exclusion.

Taking into account the health resource demand consequences of the demographic ageing on one hand and the progress and innovation in medical science on the other, good public health policies in Romania (as elsewhere) will have to become more focused on major objectives, will have to develop feasible action plans and will have to be properly financed if the system is to serve the public effectively. Sadly the Romanian National Health Strategy for 2014-2020 and the Action Plan for the Implementation of the National Strategy for 2014-2020 are examples of bureaucratic documents that two years after their adoption have yet to produce measurable effects.

\footnotetext{
7 According to EUROSTAT in 2014 Romania allocated $0.38 \%$ of GDP, much lower than the EU average of $2.3 \%$.
} 


\section{Conclusions}

Nowadays both the public at large and the policy makers have at the centre of their attention the issue of public health. The demographic ageing and the increase in life expectancy at birth are two of the major factors that put the spotlight on the subject of healthcare, eliciting calls from the community to respond to the modern challenges of effective healthcare.

Welfare, as public policy objective, implies primarily the health component. The quality of healthcare and the access to it are reliant on the effective organisation and financing of the health sector, on the sector's resources, both human and technological, as well as on the strategies to generate value from all the ingredients above. The behaviour of the service providers, the interactions between the actors in the system, the material and informational resources are components that matter more and more in policy design.

Health is a dimension of life that rests on a complex of several public sectors, levels and social actors. The lack of an adequate public policy leads to the inability of the public to manage its health problems. That is why the strategies and health policies represent key ingredients in the recipe of social intervention. As long as healthcare costs are rising, the inequity engine of social exclusion will likely remain the most toxic agent affecting our health. For that reason public health policies need the support of social inclusion ones.

While in Romania social inclusion has been for some time on the agenda of social policy makers, it only now that the issue of health is being looked upon as another risk factor for exclusion. Those at risk of social exclusion are facing not just exclusion from the labour market or from education, but also exclusion from the opportunity of a healthy life and that is why health policy cannot be a medical sector-only issue, but a cross-sector concern. 


\section{References}

Alianța pentru Sănătate din România. n.d. 'România. Starea de fapt în asigurările sociale' http://www.medicalmanager.ro/docs/raportul_ apsr_-_sistemul_de_asigurari_de_sanatate_din_romania_2014.pdf (18.01.2016).

Baggott, Rob. 2011. Public Health: Policy and Politics. Palgrave: Macmillan.

Bhattacharya, Dru. 2013. Public Health Policy: Issues. Theories, and Advocacy. San Francisco: Jossey-Bass.

Bryant, Toba. 2009. An introduction to health policy. Toronto: Canadian Scholars' Press Inc.

Buse, Kent, Nicholas Mays, and Gill Walt. 2012. Making Health Policy. 2. ed. Understanding Public Health. Maidenhead: Open Univ. Press.

Buțiu, Călina-Ana. 2014. Bunăstarea, încotro? Spre o nouă paradigmă în politicile sociale. Cluj-Napoca: Presa Universitară Clujeană.

Byrne, David. 2010. 'Future priorities in EU health policies'. European Health Forum on Common Challenges for Health and Care. Gastein, 26 September 2002. SPEECH/02/426.

Carter, Jean and Marion Slack. 2010. Pharmacy in Public Health: Basics and Beyond. Bethesda: American Society of Health System Pharmacists.

Casa Națională de Asigurări de Sănătate. 2010. Ordin comun MS/ CNAS nr. 44/53/ 2010 privind aprobarea unor măsuri de eficientizare a activității la nivelul asistenței medicale ambulatorii în vederea cresterii calității actului medical încadrul sistemului de asigurări sociale de sănătate. Publicat in Monitorul Oficial Nr. 131/ 26.02.2010.

Comisia Europeană. 2010. Platforma europeană de combatere a sărăciei şi a excluziunii sociale: un cadru european pentru coeziunea socială şi teritorială. Bruxelles. 16.12.2010. $\mathrm{COM(2010)} 758$ final. 02.02.2014. http:/ / eur-lex.europa.euLexUriServ / LexUriServ.do?uri=COM:2010: 0758:FIN:RO:PDF.

Dror, Yehezkel. 1983. Public policymaking reexamined. New Jersey: Transaction Publishers.

Eisner, Marc Allen, Jeffrey Worsham, and Evan J. Ringquist. 2006. Contemporary Regulatory Policy. 2nd ed. Boulder: Lynne Rienner Publishers.

European Comission (EC). 2014. Special Eurobarometer 411. Patient Safety and Quality of Care. June 2014, http://ec.europa.eu/public_opinion/ archives/ebs/ebs_411_fact_ro_en.pdf. (02.02.2015).

Evans, David B, Ajay Tandon, Christopher J. L. Murray, and Jeremy A. Lauer. 2001. 'Comparative Efficiency of National Health Systems: 
Cross National Econometric Analysis.' BMJ 323(7308): 307-10. doi:10.1136/bmj.323.7308.307.

Evashwick, Connie, J. 2013. 'Public Health Workforce and Education in the United States'. In Contemporary Public Health. Principles, Practice, and Policy, edited by James W. Holsinger, 63-84. Lexington: University Press of Kentucky.

Franklin, Paula. 2013. 'European Public Health Strategies.' Eurohealth 19(4): 31-34. http://www.euro.who.int/_data/assets/pdf_file/0003/ 236811/Eurohealth_v19-n4.pdf. (14.04.2016).

Guvernul României. 2014a. Hotărâre Nr. 400 din 13 mai 2014 Pentru aprobarea pachetelor de servicii şi a Contractului-cadru care reglementează condițiile acordării asistenței medicale in cadrul sistemului de asigurări sociale de sănătate pentru anii 2014 - 2015: Monitorul Oficial Nr. 366 din 19 mai 2014.

Guvernul României. 2014b. Hotărârea Nr. 1028/2014 privind aprobarea Strategiei naționale de sănătate 2014-2020 şi a Planului de acțiuni pe perioada 2014-2020 pentru implementarea Strategiei naționale: Monitorul Oficial Nr. 891 din 08.12.2014

Hester, Micah D. 2006. 'Professing Public Health: Practicing Ethics and Ethics as Practice.' In Public Health Policy and Ethics, edited by Michael Boylan, 1-16. New York: Kluver Academic Publishers.

Holsinger, James Jr., and Douglas F. Scutchfield. 2013. 'Introduction: History and Context of Public Health Care'. In Contemporary Public Health. Principles, Practice, and Policy, edited by James W. Holsinger Jr., 1-24. Lexington: University Press of Kentucky.

Isar, Lucian. 2014. 'Noua strategie de sănătate, un progres în spirit paternalist-libertarian', Vox Publica, 17.01 2014, http://voxpublica.realitatea.net/ politica-societate/noua-strategiede-sanatate-un-progres-in-spirit-paternalist-libertarian-101685.html (29.03.2016).

Jenkins, William. 1978. Policy Analysis: A Political and Organizational Perspective. London: Martin Robertson.

Parlamentul României. 2008. Legea farmaciei Nr. 266/2008 cu modificările şi completările ulterioare. Monitorul Oficial, Partea I Nr. 765 din 13/11/2008.

Parlamentul României. 2006. Legea Nr. 95/2006 din 14 aprilie 2006 privind reforma în domeniul sănătății. Monitorul Oficial Nr. 372/28 aprilie 2006.

Parlamentul României. 2011. Legea nr. 292/2011 legea asistenței sociale. Monitorul Oficial Nr. 905/20 decembrie 2011. 
Matthews, Jeanne. 2009. 'Core functions of Public Health Nursing.' In Public Health Nursing. Leadership, Policy EPractice, edited by L. Louise Ivanov and Carolyn L. Blue, 27-56. New York: Delmar Cengage Learning.

Ministerul Sănătătii. 2012. Lege privind Organizarea şi funcționarea sistemului de sănătate din România - Proiect, http://www.ms.ro/upload/Lege\% 2002\% 2007\% 202012.pdf (01.02.2016).

Ministerul Sănătății. 2014. 'Strategia Națională de Sănătate 2014 - 2020', Anexa 1 la Hotărâre Nr. 1028 din 18 noiembrie 2014 privind aprobarea Strategiei naționale de sănătate 2014 - 2020 şi a Planului de acțiuni pe perioada 2014 - 2020 pentru implementarea Strategiei naționale, Monitorul Oficial al României, Partea I, Nr. 891 bis.

Ministerul Sănătății Publice. 2008. Ordinul Nr. 39/2008 privind reorganizarea ambulatoriului de specialitate al spitalului. Monitorul Oficial al României, Partea I. Nr. 39, 16.01.2008.

Păceşilă, Mihaela. 2008. 'Actorii Implicati în Ciclul Politicilor Publice Stakeholderi ai politicilor publice'. Cercetări practice şi teoretice în managementul urban / Theoretical and Empirical Researches in Urban Management 3(8): 84-93.

Petersen, Alan and Deborah Lupton. 2000. The New Public Health. Health and self in the age of risk. London: SAGE Publications.

Pop, Cosmina-E. 2010. 'Starea de sănătate a populației din România în context European. $\mathrm{O}$ abordare din perspective calității vieții' . Revista Calitatea Vieții XXI(3-4): 274-305.

Porche, Demetrius J. 2012. Health Policy. Applications for Nurses and Other Healthcare Professionals. New Orleans: Jones \& Bartlett Learning.

Powers, Madison and Ruth Faden. 2008. Social Justice: The Moral Foundations of Public Health and Health Policy. New York: Oxford University Press.

Ritli, Ladislau. n.d. Expunerea de motive a Legii privind Organizarea şi funcționarea sistemului de sănătate din România, www.economiesociala.net/imag/files.../20814555264f05a00b96a64.d oc, (15.02.2016).

Roemer, Milton I. 1993. National Health Systems of the World : Volume II. New York: Oxford University Press.

Rose, Richard. 2005. Learning from Comparative Public Policy. London: Routledge.

Seltzer, Beth. 2011. 101 Careers in Public Health. New York: Springer Publishing Company.

Woolf, Steven H., and Paula Braveman. 2013. 'The social and Ecological Determinants of Health.' In Contemporary Public Health. Principles, 
Practice, and Policy, edited by James W. Holsinger Jr., 25-46. Lexington: University Press of Kentucky.

World Bank. 2011. Romania - Functional review : health sector. Washington, DC: World Bank. http://documents.worldbank.org/curated/en /2011/05/17056888/romania-functional-review-health-sector (14.02.2016).

World Health Organization (WHO). 2013. Health 2020: a European policy framework and strategy for the 21st century. Copenhagen: WHO Regional Office for Europe. http://www.euro.who.int/en/ publications/abstracts/health-2020-a-european-policy-frameworkand-strategy-for-the-21st-century (05.05.2015).

World Health Organization (WHO). 2014. Qualitative indicators for monitoring Health 2020 policy target. Copenhagen: WHO Regional Office for Europe.

World Health Organization (WHO). 2015. Taking a participatory approach to development and better health. Examples from the Regions for Health Network. Copenhagen: WHO Regional Office for Europe. 